\title{
Oxyphil Cell Metaplasia in the Parathyroids Is Characterized by Somatic Mitochondrial DNA Mutations in NADH Dehydrogenase Genes and Cytochrome $c$ Oxidase Activity-Impairing Genes
}

Josef Müller-Höcker, ${ }^{*}$ Sabine Schäfer, ${ }^{*}$ Stefan Krebs, ${ }^{\dagger}$ Helmut Blum, ${ }^{\dagger}$ Gábor Zsurka, ${ }^{\ddagger}$ Wolfram S. Kunz,${ }^{\ddagger}$ Holger Prokisch, Peter Seibel, "बand Andreas Jung*\|

From the Institute for Pathology of the Ludwig-Maximilians-Universität München, * Munich; the Gene Center of the Ludwig-Maximilians-Universität München, ${ }^{\dagger}$ Campus Großhadern, Munich; the Division of Neurochemistry, ${ }^{\ddagger}$ Department of Epileptology and Life and Brain Center, University of Bonn, Bonn; the Institute of Human Genetics, ${ }^{\S}$ Helmholtz-Zentrum München, Neuherberg; the Molekulare Zellbiologie, ${ }^{\llbracket}$ Biotechnological Biomedical Center, Universität Leipzig, Leipzig; and the German Cancer Consortium and German Cancer Research Center," Heidelberg, Germany

Accepted for publication

July 17, 2014.

Address correspondence to Andreas Jung, Ph.D., Institute of Pathology, Ludwig-Maximilians-Universität München, Thalkirchnerstrasse 36, 80337 München, Germany. E-mail: andreas.jung@1mu.de.

\begin{abstract}
Oxyphil cell transformation of epithelial cells due to the accumulation of mitochondria occurs often during cellular aging. To understand the pathogenic mechanisms, we studied mitochondrial DNA (mtDNA) alterations in the three cell types of the parathyroids using multiplex real-time PCR and nextgeneration sequencing. mtDNA was analyzed from cytochrome $c$ oxidase (COX)-positive and COXnegative areas of 19 parathyroids. Mitochondria-rich pre-oxyphil/oxyphil cells were more prone to develop COX defects than the mitochondria-poor clear chief cells $(P<0.001)$. mtDNA increased approximately 2.5-fold from clear chief to oxyphil cells. In COX deficiency, the increase was even more pronounced, and COX-negative oxyphil cells had approximately two times more mtDNA than COXpositive oxyphil cells $(P<0.001)$, illustrating the influence of COX deficiency on mtDNA biosynthesis, probably as a consequence of insufficient ATP synthesis. Next-generation sequencing revealed a broad spectrum of putative pathogenic mtDNA point mutations affecting NADH dehydrogenase and COX genes as well as regulatory elements of mtDNA. NADH dehydrogenase gene mutations preferentially accumulated in COX-positive pre-oxyphil/oxyphil cells and, therefore, could be essential for inducing oxyphil cell transformation by increasing mtDNA/mitochondrial biogenesis. In contrast, COX-negative cells predominantly harbored mutations in the MT-CO1 and MT-CO3 genes and in regulatory mtDNA elements, but only rarely NADH dehydrogenase mutations. Thus, multiple hits in NADH dehydrogenase and COX activity-impairing genes represent the molecular basis of oxyphil cell transformation in the parathyroids. (Am J Pathol 2014, 184: 2922-2935; http://dx.doi.org/10.1016/j.ajpath.2014.07.015)
\end{abstract}

Parathyroids are made up of three cell types: i) clear chief cells containing low amounts of mitochondria, ii) mitochondria-rich pre-oxyphil cells, and iii) mitochondria-rich oxyphil cells. The proportion of mitochondria-rich cells increases with age, ${ }^{1}$ such as in other organs, where such cells are called oncocytes., Oncocytes may produce oncocytic neoplasias, also known as oncocytomas. Oncocytes, pre-oxyphil cells, and oxyphil cells characteristically show an eosinophilic fine granular cytoplasm caused by their many mitochondria. In previous studies, we showed that defects of the respiratory chain, especially cytochrome $c$ oxidase (COX), the terminal enzyme of the respiratory chain in the mitochondria, occur in hyperfunctional parathyroids and during aging, ${ }^{4-6}$ where especially the mitochondria-rich pre-oxyphil and oxyphil cells are affected. Similar COX defects were found in the liver, both in normal

Supported by Deutsche Forschungsgemeinschaft grants KU 911/21-1 (W.S.K.) and ZS 99/3-1 (G.Z.) and the European Community (FP7 project EpiPGX) grant 279062 (W.S.K.).

Disclosures: None declared. 
and in mitochondria-rich (oncocytic) hepatocytes, ${ }^{7-9}$ occurring with increased frequency during aging. ${ }^{8}$

Generally, the regulatory mechanisms of mitochondrial biogenesis under pathological conditions are poorly understood, but most probably a disturbance of oxidative phosphorylation leading to energy deficiency is a major driving force. Such energy deficiencies might be due to mutations in mitochondrial (mtDNA) or nuclear (nDNA) DNA, as it is best described in mitochondrial encephalomyopathies. ${ }^{10-18} \mathrm{~A}$ frequently observed mtDNA mutation in encephalomyopathies is the so-called common 4977-bp deletion, ${ }^{19}$ and this mutation also occurs in mitochondria-rich oxyphil Askanazy cells of Hashimoto thyroiditis and in goiters, in thyroid tumors with and without oncocytic cell change, ${ }^{20,21}$ and in the oncocytic cells of Warthin tumors. ${ }^{22} \mathrm{~A}$ major pathogenic role has been attributed to point mutations of mitochondrial NADH dehydrogenase genes (ND; complex I of the respiratory chain) in mitochondria-rich oncocytic neoplasms of various organs. ${ }^{23-30}$ Similarly, $N D$ gene mutations were also demonstrated in oncocytic adenomas of the parathyroids, ${ }^{31}$ but the involvement of the different cell types of the parathyroid gland and the role of COX deficiency in the process of oxyphil cell transformation have not been specifically addressed. Therefore, we compared the mutational status of mtDNA in the three cell types in the states of both COX positivity and negativity by quantitative real-time PCR (qPCR) and next-generation sequencing (NGS) for better understanding the pathomechanisms in oxyphil cell transformation.

\section{Materials and Methods}

\section{Enzyme Histochemistry}

Frozen tissue sections of 19 hyperfunctional parathyroids (primary hyperparathyroidism, $n=15$; secondary hyperparathyroidism, $n=4$; males, $n=9$; females, $n=10$; age range, 25 to 80 years) were stained in series for hematoxylin and eosin (H\&E), COX, and succinate dehydrogenase (SDH), individually or in combination. ${ }^{32}$ Morphologically, the parathyroids represented adenomas and hyperplasias and were of mixed cell type showing mitochondria-poor clear chief cells, mitochondria-rich pre-oxyphil/transitional, and oxyphil cells, the two latter being characterized by an eosinophilic cytoplasm that is most intense in oxyphil cells because of their highest content of mitochondria (Figure 1). Pure oxyphil or chief cell adenomas were not included in the study. For studying mtDNA, selective sampling was done for COX-positive and COX-negative clear chief cells, pre-oxyphil cells, and oxyphil chief cells by laser-capture microdissection using a combined COX-SDH stain for discriminating COX-positive and COXnegative areas, as previously described. ${ }^{33}$ COX-negative areas stained blue for $\mathrm{SDH}$, whereas $\mathrm{COX}$-positive areas stained brown for the COX stain (Figure 2), with different intensities according to the differential mitochondrial content of the three cell types. Thus, on the basis of the differential
COX-staining intensities, the mitochondria-poor clear chief cells, mitochondria-rich pre-oxyphil/transitional cells, and oxyphil cells could easily be discriminated. On the whole, 189 areas, 102 without and 87 with COX defects, were analyzed.

The number and size of COX-defective areas varied considerably between cases in the entire study group and also in the five cases analyzed for next-gene sequencing, with $6,11,12,13$, or 25 defect areas in cases $3,4,1,5$, and 2 , respectively. The largest defect areas occurred in cases 3 (4-mm diameter) and 4 (6-mm diameter), whereas the other defects were approximately $\leq 1 \mathrm{~mm}$ in diameter. Consequently, the percentage of the defect areas varied between approximately $1 \%$ and $10 \%$ of the tissues.

\section{Molecular Genetics}

Total DNA was extracted using a QIAamp DNA Minikit (Qiagen, Hilden, Germany), according to the manufacturer's recommendations.

\section{Real-Time qPCR}

Deletions of the mtDNA were detected by qPCR. Essentially, two regions of the mtDNA were identified that were

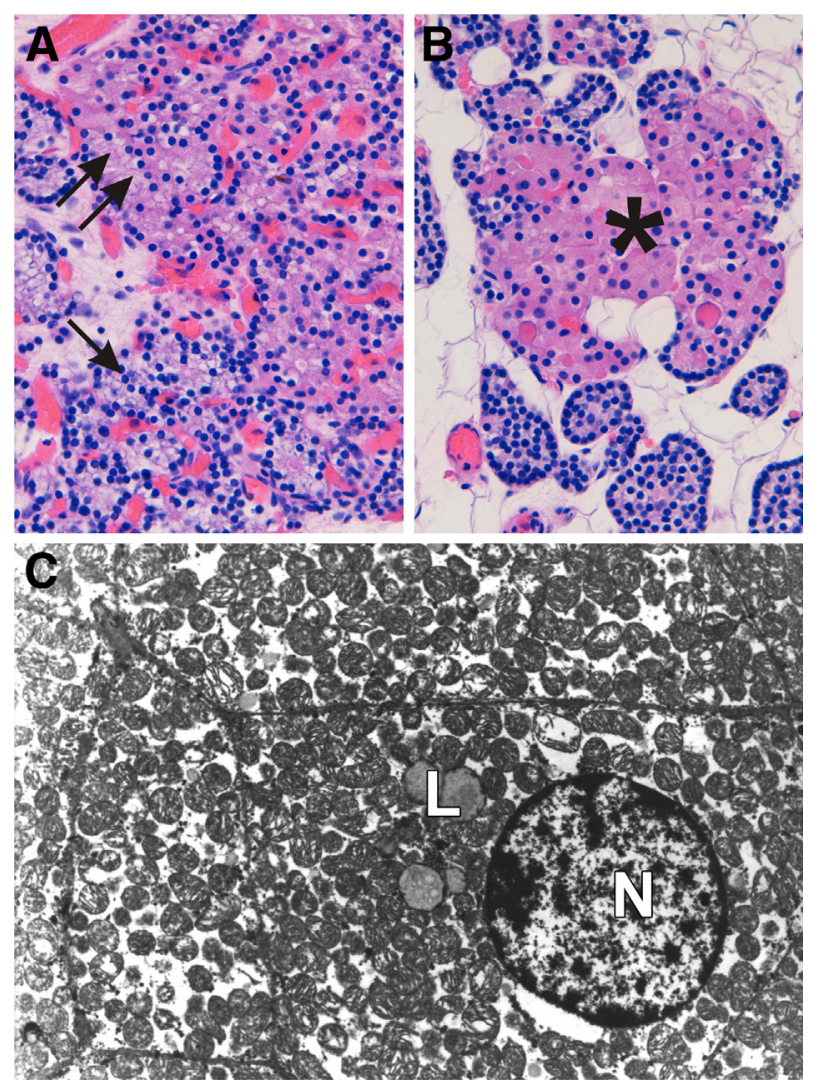

Figure 1 Histological features of the parathyroid gland. A: Regular clear chief cells (single arrow) have a clear cytoplasm close to pre-oxyphil cells (double arrow) with a fairly eosinophilic cytoplasm due to an increase in mitochondria. B: 0xyphil cells (asterisk) show the most intense eosinophilic cytoplasm because of the highest content of mitochondria. C: Electron micrograph of an oxyphil cell. The cytoplasm is stuffed full of mitochondria. Original magnifications: $\times 40(\mathbf{A}$ and $\mathbf{B}) ; \times 10,000$ (C). L, lipid droplet; N, nucleus. 
located either outside or inside of commonly deleted regions in most patients with mtDNA abnormalities, thus producing amplification measures of total or intact mtDNA, respectively. Used PCR primers, fluorescent probe, and analysis models are published. ${ }^{34}$

To rule out artificial influences of the PCR maneuver, only deletions $\geq 15 \%$ were accepted to be valid.

$$
\frac{\mathrm{mtDNA}}{\text { nuclear DNA }}\left(\mathrm{Q}_{\mathrm{mt} / \mathrm{n}}\right)
$$

The ratio of mtDNA/nDNA was also determined by qPCR. The primers were designed for parts of the nuclear reference gene encoding the 12S rRNA (12S-1036-forward, 5'-AGTCGGAGGTTCGAAGACGAT-3'; 12S-1127-reverse, 5'-GCGGGTCATGGGAATAACG- $3^{\prime}$ ) and the mitochondrial reference gene encoding ND1 (4094-forward, 5'-CCCTACTTCTAACCTCCCTGTTCTTAT-3'; 4175-reverse, $5^{\prime}$-CATAGGAGGTGTATGAGTTGGTCGTA-3'). For qPCR, MasterMix Plus for SYBR Green I Low ROX-Kit (Eurogentec, Brussels, Belgium) was used in a total volume of $30 \mu \mathrm{L}$, supplemented with $200 \mathrm{nmol} / \mathrm{L}$ of each primer following the supplier's recommendations.

\section{Library Preparation and Next-Generation Sequencing}

DNA was isolated from five parathyroids using QIAamp DNA micro kits (Qiagen), resulting in DNA amounts between 107 and 484 ng (Table 1). For each sample (except sample 1, $100 \mathrm{ng}$ ), $200 \mathrm{ng}$ of purified DNA was fragmented by sonication (Bioruptor, Diagenode, Liege, Belgium) (settings: 25 cycles of 30 seconds on/30 seconds off, low energy) and subsequently subjected to end repair, A-tailing, and adaptor ligation using the NEXTflex DNA sequencing kit (Bioo Scientific, Austin, TX) following the manufacturer's protocol. Purifications after end repair and ligation were done with Agencourt AMPure Xp beads (Agencourt, Indianapolis, IN), followed by PCR amplification (2 minutes at $98^{\circ} \mathrm{C} ; 15$ cycles of 30 seconds at $98^{\circ} \mathrm{C}, 30$ seconds at $65^{\circ} \mathrm{C}$, and 60 seconds at $72^{\circ} \mathrm{C} ; 4$ minutes at $72^{\circ} \mathrm{C}$ ) using different six-nucleotide barcode primers (NEXTflex DNA barcodes; Bioo Scientific) for each of the 24 samples. Samples were quantified on an Agilent 2000 bioanalyzer

Table 1 mtDNA in the Three Histological Cell Types of the Parathyroids with Intact (COX-Positive) or Deficient (COX-Negative) COX Activity

\begin{tabular}{lllr}
\hline Histological cell type & COX positive & COX negative & $P$ value* $^{*}$ \\
\hline Clear chief & 0.32 & 0.44 & 0.152 \\
& $(n=26)$ & $(n=23)$ & \\
Pre-oxyphil & 0.64 & 0.81 & 0.213 \\
& $(n=23)$ & $(n=39)$ & \\
Oxyphil & 0.82 & 1.74 & $<0.001$ \\
& $(n=47)$ & $(n=22)$ & \\
$P$ value & $<0.001$ & $<0.001$ & \\
\hline
\end{tabular}

Median value of the ratio mtDNA:nDNA.

*Wilcoxon test (two sided).
(Agilent, Santa Clara, CA). Equimolar amounts of the 24 samples were pooled to prepare the subsequent capture on a $244 \mathrm{k}$ feature array designed by Agilent's e-array software to enrich for the mitochondrial genome using standard repeat
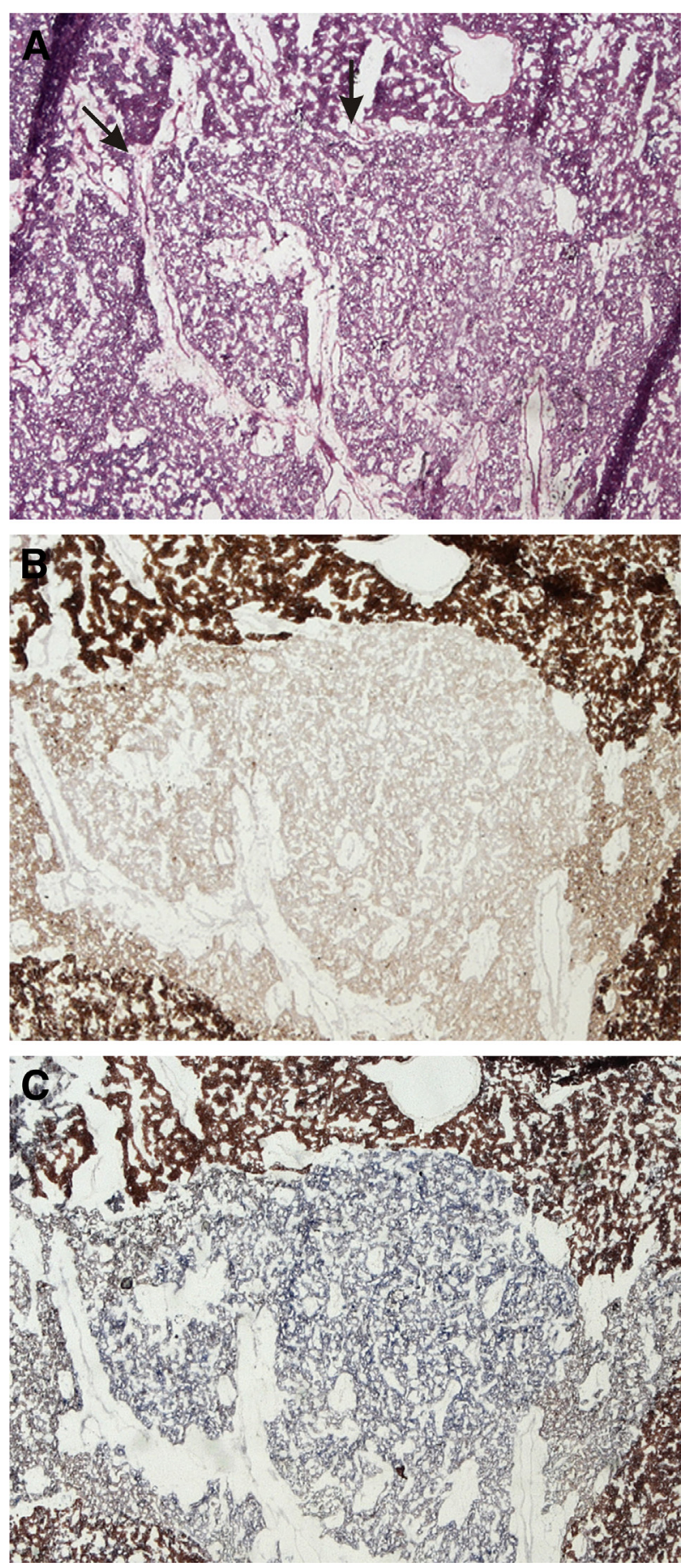

Figure 2 Clear chief cells lack COX activity. A: H\&E stain shows weakly stained clear cell area (arrows). B: In the COX stain, the clear cell area lacks activity, whereas oxyphil cells in the surrounding areas react intensively because of their high content of mitochondria. C: COX-SDH stain shows a weakly blue SDH stain (low content of mitochondria) within the COX-deficient area and an intense brown reaction outside in oxyphil cells (positive COX reaction, masked SDH reaction). Original magnification, $\times 10(\mathbf{A}-\mathbf{C})$. 
masking and 3-bp tiling. One single custom-synthesized array (Agilent 244k capture array; Agilent) was used for generating a pool of eight equimolar libraries, according to the manufacturer's protocols. Briefly, the libraries were hybridized at $65^{\circ} \mathrm{C}$, washed, and eluted with nuclease-free water for 10 minutes at $95^{\circ} \mathrm{C}$. The eluted DNA was concentrated in a vacuum centrifuge, amplified in 10 PCR cycles ( 15 seconds at $98^{\circ} \mathrm{C}, 30$ seconds at $65^{\circ} \mathrm{C}, 30$ seconds at $72^{\circ} \mathrm{C}$ ), and purified with Ampure XP beads (Agencourt). The multiplexed and enriched libraries were sequenced on a single lane of a flow cell on an Illumina Genome Analyzer IIx (Illumina, San Diego, CA) in paired-end configuration. Mean read length was $78 \mathrm{bp}$ for the forward read, $7 \mathrm{bp}$ for the indexing read, and $85 \mathrm{bp}$ for the reverse read. The raw data (FASTQ files) were analyzed using a Galaxy platform (http://www.galaxy.org). ${ }^{35}$

\section{Bioinformatical Analysis}

Alignment of sequence reads to the human mitochondrial reference sequence (NC_012920) was performed using a custom Perl script implementing a heuristic local alignment algorithm. Therefore, we were able to identify sequence reads that aligned either continuosusly or discontinuously. Only full-length reads were considered, where each nucleotide had a minimum quality score of 20 . Reads that had more than three mismatches were excluded from the analysis. Information about single-nucleotide positions was collected from high-quality continuous reads, discarding the first and the last five positions in each read. Only mutations with at least $20 \%$ degree of heteroplasmy were considered. Functional assignment of base changes was performed using the MitoWheel web-based tool (http://mitowheel.org, last accessed July 16, 2014). Breakpoints were identified in reads, where two parts of the sequence matched unambiguously two distinct regions of the mitochondrial genome, and none of the matches was $<12$ nucleotides.

\section{Statistical Analysis}

Statistical significance was tested by applying Wilcoxon or $\chi^{2}$ modelling using SPSS software version 21 (IBM, Armonk, NY). Differences were considered to be significant when a one-sided $\alpha$-error of $<5 \%$ was reached $(P<0.05)$.

\section{Results}

COX Deficiency Affects Predominantly Pre-0xyphil and Oxyphil Cells

To detect defects of COX, enzyme histochemistry was applied on 19 parathyroids. On the whole, 87 areas with COX defects were found. The defects were localized in clear chief cells, pre-oxyphil cells, and oxyphil cells, often forming small nodules (Figures 2, 3, and 4). Of the defects, 75\% (65/87) occurred in pre-oxyphil/oxyphil cells, but only $25 \%(22 / 87)$
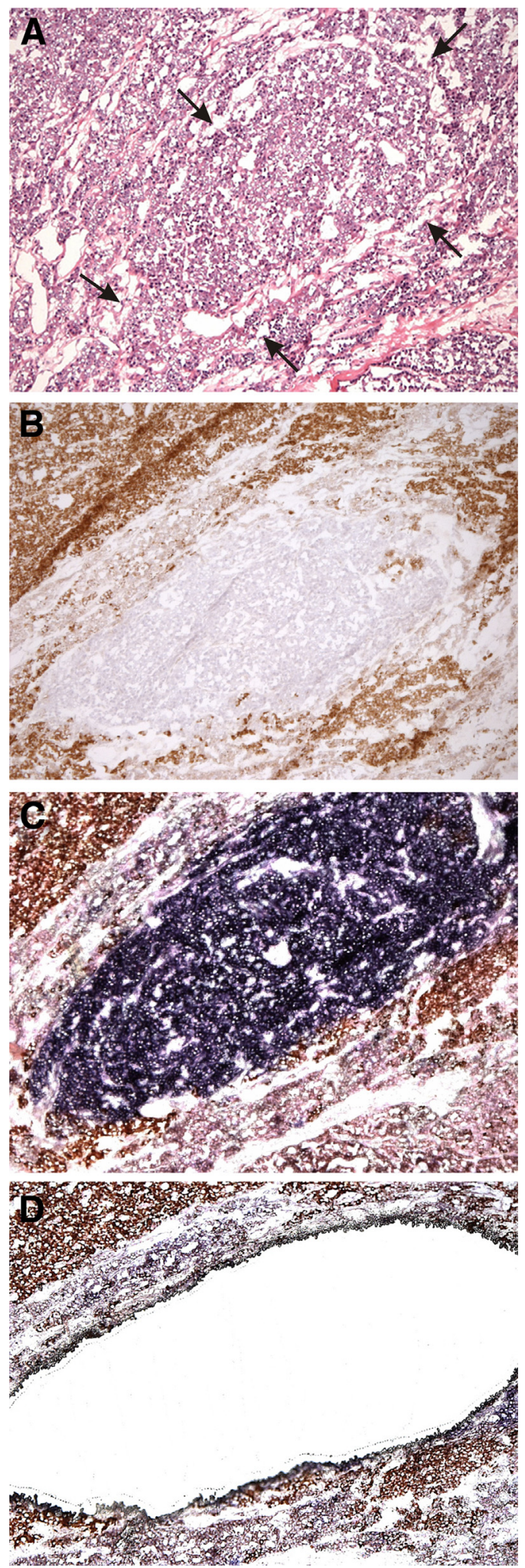

Figure 3 Pre-oxyphil cells lack COX activity. A: H\&E stain shows a cell nodule (arrows) of weakly eosinophilic cells lacking COX activity. B: In contrast, pre-oxyphil cells in the surrounding areas react intensely. C: In the COX-SDH stain, SDH in the COX-defective nodule reacts intensely. In the surrounding areas, the COX reaction is intense in pre-oxyphil cells. D: The SDH staining remains masked. COX-deficient nodule after laser microdissection (COX-SDH stain). Original magnifications: $\times 10($ A $-C) ; \times 2.5$ (D). 

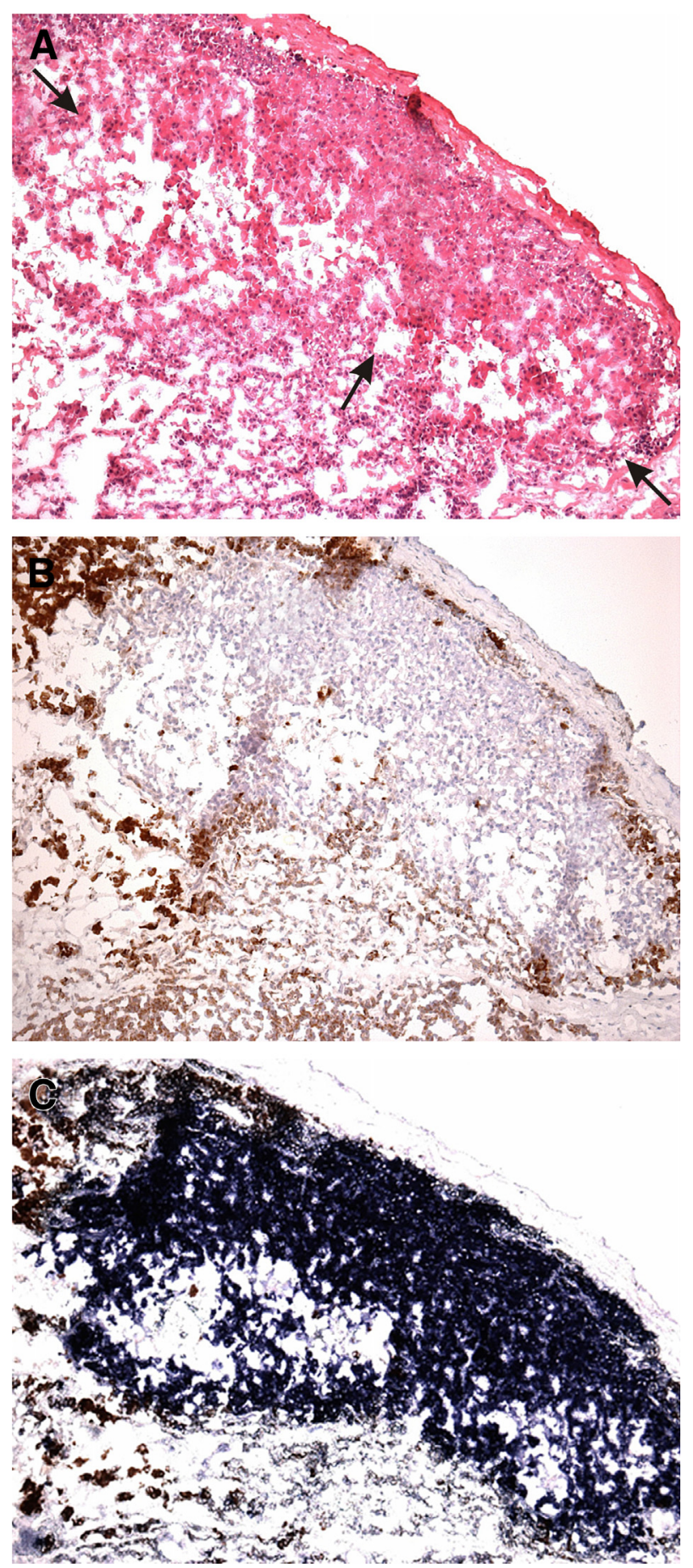

Figure 4 0xyphil cells lack COX activity. H\&E stain shows intense eosinophilic cells of an oxyphil nodule (arrows, A), which lack COX activity (B). C: COX-SDH stain. In the COX-defective area SDH is unmasked reacting dark blue according to many mitochondria (for comparison, see the weaker SDH staining of pre-oxyphil cells in Figure $3 \mathrm{C}$ ). In the surrounding areas the positive brown COX-reaction is preserved. Original magnification, $\times 10(\mathbf{A}-\mathbf{C})$.

occurred in chief cells. The size of the defects varied between $<1$ and up to $6 \mathrm{~mm}$ in diameter. COX-negative clear chief cells stained light blue in the combined COX-SDH stain (Figure 2C) because of their low content of mitochondria. Expectedly, COX-negative pre-oxyphil cells and COX-negative oxyphil cells reacted more or respectively most intensively because of their higher or respectively highest content of mitochondria (Figures 3C and 4C). In contrast, in COX-positive oxyphil cells, blue SDH staining remained masked, thus allowing a clear differentiation of COX-positive from COX-negative cells. An isolated SDH stain did not reveal differential staining intensity between the same COX-positive and COXnegative cell types (data not shown). Therefore, no increase of mitochondrial content was detectable at the histological level in COX-negative cells when compared with their COXpositive counterparts.

\section{$\mathrm{Q}_{\mathrm{mt} / \mathrm{n}}$ Is Highest in COX-Negative 0xyphil Cells}

Molecular genetic analysis was performed on COX-positive and COX-negative foci of the various cell types (Figure 3, B-D) collected by laser-capture microdissection by applying qPCR. We found no evidence for mtDNA depletion in the different cell types irrespective of COX activity. On the contrary, in COX-positive cells, the mean ratio increased significantly $\left(\mathrm{Q}_{\mathrm{mt} / \mathrm{n}}\right.$ approximately 2.5 -fold; $\left.P<0.001\right)$ from mitochondria-poor clear chief to oxyphil cells corresponding to a high content of mitochondria in the latter (Table 1 and Figure 5). In COX-negative cells, the increase in mtDNA was even more marked $\left(\mathrm{Q}_{\mathrm{mt} / \mathrm{n}}\right.$ approximately fourfold; $P<0.001)$. Interestingly, in COX-negative oxyphil cells, the mtDNA content was additionally doubled compared with the identical COX-positive cell type $\left(\mathrm{Q}_{\mathrm{m} t / \mathrm{n}}\right.$ approximately twofold; $P<0.001$ ), indicating a more pronounced increase of mtDNA biosynthesis in COX deficiency.

\section{Large-Scale Deletions Are Not of Pathogenic Significance}

mtDNA-specific multiplex qPCR of 189 areas (102 COX positive and 87 COX negative) revealed deletions only in

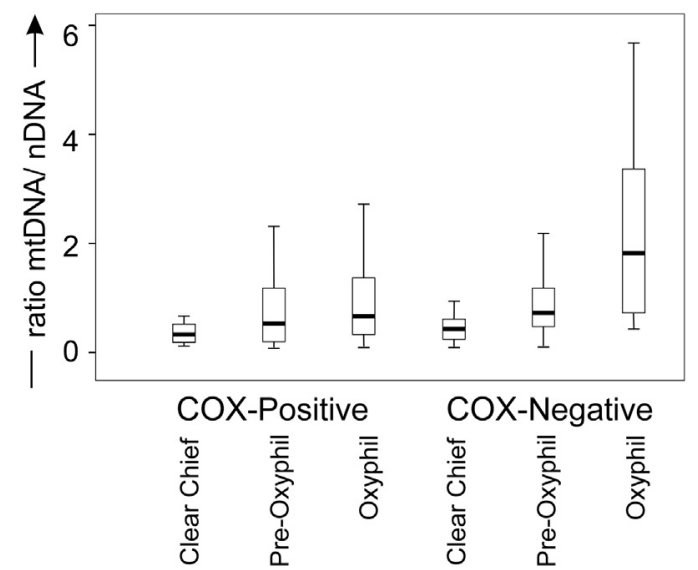

Figure 5 mtDNA content (mtDNA:nDNA). In both COX-positive and COXnegative cells, the mtDNA content increases from clear chief cells via preoxyphil to oxyphil cells, with COX-negative cells containing generally more mtDNA. This is most significant for oxyphil cells, where the amounts are more than doubled (Table 1), indicating increased mtDNA biogenesis in COX deficiency. 
$24 \%$ of COX-positive $(24 / 102)$ and $25 \%$ of COX-negative (22/87) areas. Specifically, of the three cell types (clear chief, pre-oxyphil, and oxyphil cells), only clear chief cells displayed an increased frequency of deletions in COX deficiency $(P<0.03)$ (Table 2$)$. Also, the amount of deleted mtDNA increased exclusively in clear chief cells $(P<0.001)$ (Table 3). However, because the increase in deleted mtDNA was restricted to a subfraction of clear chief cells (Tables 2 and 3), we did not regard mtDNA deletions to play a primary pathogenic role in oxyphil cell transformation and, therefore, looked for point mutations of mtDNA.

\section{Polymorphisms and Putative Pathogenic Mutations of mtDNA}

NGS was performed using DNA from each of 12 COXpositive and COX-negative areas from five parathyroid glands [four adenomas (cases 1 to 4 ) and one case with secondary hyperplasia (case 5)] (Table 4). The amount of recovered DNA was lowest in case 1 (107 to $164 \mathrm{ng}$ per area), whereas it ranged between 345 and $484 \mathrm{ng}$ per area in cases 2 to 5 (Table 4 ).

The areas were classified into types 1 to 6 (Table 4) with COX-positive clear chief cells (type 1), pre-oxyphil cells (type 2), and oxyphil cells (type 3), and COX-negative clear chief cells (type 4), pre-oxyphil cells (type 5), and oxyphil cells (type 6). Two groups of genetic alterations were defined on the basis of their frequency in the population and position in the mitochondrial genome. First, there were rare missense (and nonsense) and frame shift mutations in protein-coding genes. Also, there were mutations in tRNA or rRNA genes, and at conserved regulatory regions of the mitochondrial genome, which were considered as functionally relevant and, thus, potentially disruptive (Table 5). These were termed, therefore, putative pathogenic mutations. Second, there were synonymous and frequent missense mutations in protein-coding genes and polymorphisms in the noncoding region that were assumed

Table 2 mtDNA Deletions in COX-Positive and COX-Negative Areas of the Parathyroids

\begin{tabular}{lllll}
\hline \multirow{2}{*}{ Cell type } & & $\begin{array}{l}\text { COX } \\
\text { positive }\end{array}$ & $\begin{array}{l}\text { COX } \\
\text { negative }\end{array}$ & Total \\
\hline Clear chief & All & 29 & 22 & 51 \\
& With deletions & $5(17 \%)$ & $10(45 \%)$ & $15(29 \%)$ \\
& $P<0.03^{*}$ & & & \\
Pre-oxyphil & All & 21 & 41 & 62 \\
& With deletions & $7(33 \%)$ & $8(20 \%)$ & $15(24 \%)$ \\
& $P>0.1^{*}$ & & & \\
0xyphil & All & 52 & 24 & 76 \\
& With deletions & $12(21 \%)$ & $4(16 \%)$ & $16(21 \%)$ \\
& $P>0.1^{*}$ & & & \\
Total & All & 102 & 87 & 189 \\
& With deletions & $24(24 \%)$ & $22(25 \%)$ & $46(24 \%)$ \\
\hline
\end{tabular}

$n=19$

Only cases with deleted mtDNA $\geq 15 \%$ were considered.

${ }^{*} \chi^{2}$ Test.
Table 3 Quantity of mtDNA Deletions in the Different Histological Cell Types of the Parathyroids Displaying COX Positivity or Negativity

\begin{tabular}{lll}
\hline & \multicolumn{2}{l}{ Histological cell type } \\
\cline { 2 - 3 } CoX type & Clear chief & Pre-oxyphil/oxyphil \\
\hline Positive & $17.85(n=5)$ & $32.59(n=19)$ \\
Negative & $40.85(n=10)$ & $30.86(n=12)$ \\
$P<0.001^{*}$ & &
\end{tabular}

Median values of deleted mtDNA (\%) considering only cases with $\geq 15 \%$ deleted mtDNA as valid.

${ }^{*} \chi^{2}$ Test.

to have little functional relevance (Table 6) and were classified together as polymorphisms. Polymorphisms were generally widely distributed in different cell types of the same tissue and, therefore, considered as early occurring events, whereas putative pathogenic mutations were restricted to single cell types or lesions and, therefore, considered as late occurring events.

\section{Putative Pathogenic Mutations Accumulate in Pre-0xyphil and 0xyphil Cells}

Putative pathogenic mutations were detected in $18(75 \%)$ of the 24 investigated areas. These mutations were most frequently found in mitochondria-rich pre-oxyphil (types 2 and 5) and oxyphil (types 3 and 6) cell areas (15/18) (Table 7). Of all pre-oxyphil/oxyphil cell areas $(n=17)$, only two (11.8\%) were devoid of pathogenic mutations. Of 18 lesions, 8 (44.4\%) displayed more than one putative pathogenic mutation (Table 7). Because the microdissected foci were made up of cell clusters measuring up to 6 $\mathrm{mm}$ in diameter, it cannot be discriminated whether these multiple mutations were located in identical or different cells.

Of 24 areas, 6 (25.0\%) displayed no putative pathogenic mutations (Tables 7 and 8). As expected, two of these

Table 4 COX-Positive and COX-Negative Areas of the Parathyroids and Their DNA Amounts Analyzed by NGS

\begin{tabular}{|c|c|c|c|c|c|c|c|}
\hline \multirow[b]{2}{*}{$\begin{array}{l}\text { Case } \\
\text { no. }\end{array}$} & \multicolumn{3}{|c|}{ COX positive } & \multicolumn{4}{|c|}{ COX negative } \\
\hline & $\begin{array}{l}\text { Type } \\
1\end{array}$ & $\begin{array}{l}\text { Type } \\
2\end{array}$ & $\begin{array}{l}\text { Type } \\
3\end{array}$ & $\begin{array}{l}\text { Type } \\
4\end{array}$ & $\begin{array}{l}\text { Type } \\
5\end{array}$ & $\begin{array}{l}\text { Type } \\
6\end{array}$ & $\begin{array}{l}\text { No. of } \\
\text { areas }\end{array}$ \\
\hline 1 & $\begin{array}{l}+ \\
164\end{array}$ & $\begin{array}{l}+ \\
107\end{array}$ & $\begin{array}{l}+ \\
123\end{array}$ & $\begin{array}{l}+ \\
119\end{array}$ & $\begin{array}{l}+ \\
157\end{array}$ & NI & 5 \\
\hline 2 & $\begin{array}{l}+ \\
363\end{array}$ & NI & $\begin{array}{l}+ \\
379\end{array}$ & NI & $\begin{array}{l}+ \\
374\end{array}$ & $\begin{array}{l}++ \\
346 / 345\end{array}$ & 5 \\
\hline 3 & $\begin{array}{l}+ \\
451\end{array}$ & NI & $\begin{array}{l}+ \\
376\end{array}$ & $\begin{array}{l}+ \\
484\end{array}$ & $\begin{array}{l}+ \\
379\end{array}$ & NI & 4 \\
\hline 4 & NI & $\begin{array}{l}+ \\
455\end{array}$ & $\begin{array}{l}+ \\
371\end{array}$ & NI & $\begin{array}{l}+ \\
373\end{array}$ & $\begin{array}{l}+ \\
399\end{array}$ & 4 \\
\hline 5 & $\begin{array}{l}+ \\
463\end{array}$ & $\begin{array}{l}+ \\
345\end{array}$ & $\begin{array}{l}+ \\
475\end{array}$ & $\begin{array}{l}+ \\
331\end{array}$ & $\begin{array}{l}++ \\
385 / 391\end{array}$ & NI & 6 \\
\hline Total & 4 & 3 & 5 & 3 & 6 & 3 & 24 \\
\hline
\end{tabular}

Type 1, 4 clear chief cell; 2, 5 pre-oxyphil cell; 3, 6 oxyphil cell.

The numbers indicate the amount of DNA (ng/area) isolated from COXpositive and COX-negative tissue.

NI, no area; + , a single area; ++ , two independent areas analyzed by NGS. 
Table 5 Putative Pathogenic Mutations of mtDNA in COX-Positive and -Negative Areas of the Parathyroids

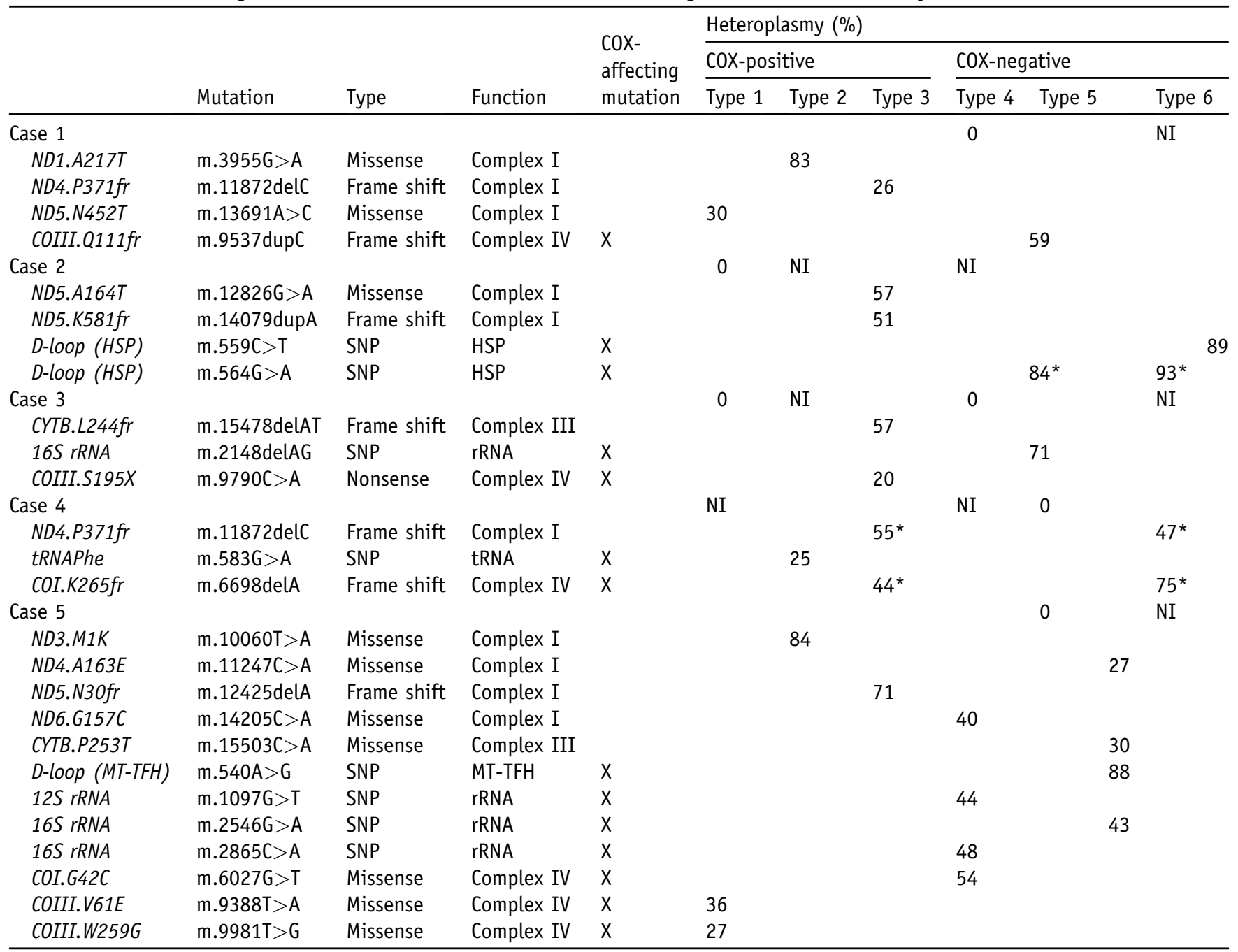

COX positive (types 1 to 3 ) and COX negative (types 4 to 6 ).

In cases 2 (type 6 ) and 5 (type 5), two independent areas were analyzed, displaying either no mutation (0) or mutations with putative functional relevance. ${ }^{*}$ Identical mutations, type 1, 4 chief cell; type 2, 5 pre-oxyphil cell; type 3, 6 oxyphil cell.

HSP, H-strand promoter; MT-TFH, mitochondrial transcription factor binding site $\mathrm{H}$; NI, no area investigated; SNP, single-nucleotide polymorphism; 0 , no mutation found.

consisted of normal COX-positive cells (type 1). In addition, two areas of COX-negative clear chief cells (type 4) and pre-oxyphil cells (type 5) lacked putative pathogenic mutations. In these cases, nuclear mutations or nondetected mtDNA mutations might be responsible for the COXnegative biochemical phenotype. It appears rather unlikely that putative pathogenic mtDNA mutations were missed because the coverage was, on average, between 194 and 2954 reads, in areas both with and without putative pathogenic mutations. Polymorphisms showed no preferential cell-type distribution and apparently were random (Table 6).

Putative Pathogenic Mutations Differ between COX-Positive and COX-Negative Cells

The observed 29 putative pathogenic mutations (Table 8) differed considerably between COX-positive and COXnegative lesions (Tables 5, 7, 8, and 9 and Figure 6).
Mitochondria-rich COX-positive pre-oxyphil/oxyphil cells (types 2 and 3) and occasionally also regular clear chief cells (type 1) harbored preferentially point mutations in the coding region of the $N D$ genes 1 and 3 to 6 of complex I and cytochrome $b$ [9 (64.3\%) of 14 mutations; $P=0.046$ ] (Tables 5 and 9 and Figure 6). In contrast, COX-deficient clear chief and pre-oxyphil/oxyphil cells (types 4 to 6 ) displayed seldom mutations in $N D$ genes or cytochrome $b$ [4 $(26.7 \%)$ of 15 ; $P=0.0046]$ (Tables 5 and 9), but rather had a broad spectrum of point mutations affecting above all of the structural genes for subunits COI and COIII, highly conserved D-loop sites (H-strand promoter region, mitochondrial transcription factor binding site) as well as the $12 \mathrm{~S}$ and $16 \mathrm{~S}$ rRNA (Tables 5 and 7 and Figure 6). As one would expect, of the 16 detected mutations potentially affecting COX, 11 occurred in COX-negative lesions (types 4 to 6, 68.8\%), but only five occurred in COX-positive lesions (types 1 to $3,31.3 \%$; 
Table 6 Polymorphisms of mtDNA in COX-Positive and -Negative Areas of the Parathyroids

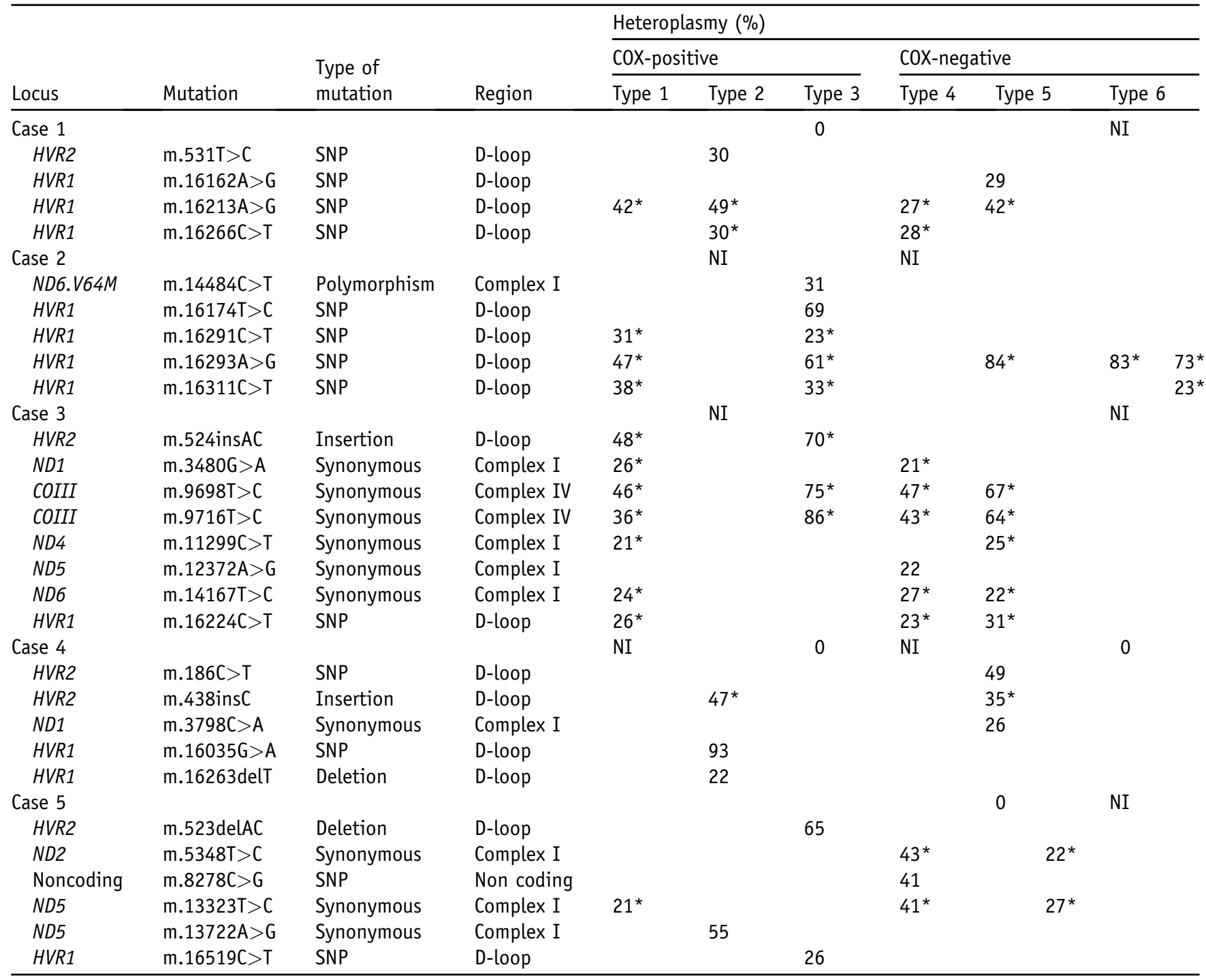

COX positive (types 1 to 3 ) and COX negative (types 4 to 6 ).

In cases 2 (type 6) and 5 (type 5), two independent areas were analyzed, displaying either no mutation (0) or mutations without putative functional relevance.

*Identical mutations, type 1, 4 chief cell; type 2, 5 pre-oxyphil cell; type 3, 6 oxyphil cell.

NI, not investigated; SNP, single-nucleotide polymorphism; 0 , negative results.

$P=0.046$ ) (Tables 7 and 9). Finally, in support with the results of the multiplex qPCR, no considerable amounts of large-scale deletions of mtDNA were detected by NGS.

\section{Heteroplasmy}

Both putative pathogenic mutations and polymorphisms were heteroplasmic (ie, samples harbored a mixture of mutant and wild-type mtDNA). The level of heteroplasmy varied considerably between $20 \%$ and $93 \%$ in the different types of lesions. Concerning putative pathogenic mutations, the highest levels of heteroplasmy occurred predominantly in COX-negative pre-oxyphil/oxyphil lesions (types 5 and 6) (Table 5). Conversely, lower heteroplasmies of mutations affecting COX were associated with COX-positive lesions (types 1 to $3 ; P<0.001$ ) (Table 5). This is in accordance with the well-known observation that most pathogenic mtDNA mutations result in functional deficiency only if their degree of heteroplasmy is above a certain threshold. For example, the heteroplasmy level of the pathogenic mutation COI.K265fr (case 4) varied between $<50 \%$ in COX-positive cells (type 3 ) and $75 \%$ in COX-negative cells (type 6). Because no single cells, but clusters of cells, were analyzed in the present study, it remains open whether the different degrees of heteroplasmy reflected true intracellular heteroplasmy levels, or resulted from variable mixtures of cells with substantially different mutation loads.

Early and Late Mutations

Polymorphisms [43 (76.8\%) of 56] (Tables 6 and 8) represented broadly expanded mutations, because they occurred in 
Table 7 Distribution of Putative Pathogenic mtDNA Mutations in COX-Positive and COX-Negative Areas of the Parathyroids

\begin{tabular}{|c|c|c|c|c|c|c|c|}
\hline \multirow[b]{2}{*}{ Variable } & & \multicolumn{3}{|c|}{ COX positive } & \multicolumn{3}{|c|}{ COX negative } \\
\hline & & Type 1 & Type 2 & Type 3 & Type 4 & Type 5 & Type 6 \\
\hline \multicolumn{8}{|l|}{ Areas } \\
\hline No. of areas & 24 & 4 & 3 & 5 & 3 & 6 & 3 \\
\hline Without putative pathogenic mutations & 6 & 2 & 0 & 0 & 2 & 2 & 0 \\
\hline With putative pathogenic mutations affecting & 18 & 2 & 3 & 5 & 1 & 4 & 3 \\
\hline $\operatorname{COX}(P<0.001)^{*}$ & 11 & 1 & 1 & $2^{\dagger}$ & $1^{\dagger}$ & $4^{\dagger}$ & $2^{\dagger}$ \\
\hline Not COX & 11 & 1 & 2 & $5^{\dagger}$ & $1^{\dagger}$ & $1^{\dagger}$ & $1^{\dagger}$ \\
\hline COX and ND & 4 & 0 & 0 & 1 & 1 & 1 & 1 \\
\hline With one mutation & 9 & 1 & 3 & 2 & 0 & 3 & 0 \\
\hline With more than one mutation & 8 & 1 & 0 & 3 & 1 & 1 & 2 \\
\hline \multicolumn{8}{|l|}{ Mutations } \\
\hline No. of mutations & 29 & 3 & 3 & 8 & 4 & 7 & 4 \\
\hline Late somatic mutations ${ }^{\ddagger}$ & 23 & 3 & 3 & 6 & 4 & 6 & 1 \\
\hline Early development mutations ${ }^{\S}$ & 6 & 0 & 0 & 2 & 0 & 1 & 3 \\
\hline Mutations affecting COX & 16 & 2 & 1 & 3 & 3 & 6 & 3 \\
\hline Mutations affecting ND & 11 & 1 & 2 & 5 & 1 & 1 & 1 \\
\hline
\end{tabular}

Areas of the parathyroid $(n=24)$.

${ }^{*} \chi^{2}$ Test comparing incidence of COX activity impairing mutations in COX-positive (types 1 to 3 ) and COX-negative (types 4 to 6 ) cells.

${ }^{\dagger}$ Areas with both COX-affecting and nonaffecting mutations.

${ }^{\ddagger}$ A single mutation (ND4.P371fr) occurring twice but in different cases (cases 1 and 4).

§Three early development mutations occurring pairwise in different areas of the same case: types 3 and 6 (two mutations: ND4.P371fr; COI.K265fr) or types 5 and 6 [one mutation: D-loop (HSP)-m.564 G > A] .

Type 1, 4 clear chief cell; type 2, 5 pre-oxyphil cell; type 3, 6 oxyphil cell.

more than one lesion of the same individual. This suggests that these mutations either arose early in development or were inherited in the heteroplasmic state ${ }^{36}$ and were, therefore, found throughout all investigated lesions of an individual. In opposite to this, only three putative pathogenic mutations showed a similar broad expansion (Table 5): i) case 2: D-loop HSP (m564G $>\mathrm{A})$ : types 5 and 6; ii) case 4: ND4.P37lfr: types 3 and 6; and iii) case 4: COI.K265fr: types 3 and 6 . The overwhelming majority of putative pathogenic mutations [23 (79.3\%) of 29] was restricted to single subclones of an individual (Tables 5 and 7). This suggests that these putative pathogenic mutations were probably generated later during life and, thus, were limited to a closely located group of cells.

Taken together, the results illustrate that, in addition to polymorphisms, multiple putative pathogenic mutations occur in the mtDNA of parathyroid cells, affecting preferentially $N D$ genes in COX-positive pre-oxyphil and oxyphil cells and COX-impairing genes in COX deficiency.

Table 8 Overview of the Distribution of Putative Pathogenic mtDNA Mutations and of Polymorphisms

\begin{tabular}{lr}
\hline Total no. of putative pathogenic mutations & 29 \\
Total no. of loci with putative pathogenic mutations & 28 \\
No. of identical loci found in different cell types & 15 \\
No. of nonidentical loci found in different cell types & 13 \\
No. of areas without putative pathogenic mutations & 6 \\
Total no. of polymorphisms & 56 \\
No. of identical polymorphisms & 43 \\
No. of nonidentical polymorphisms & 13 \\
No. of areas without polymorphisms & 4 \\
\hline
\end{tabular}

However, because only 24 areas derived from five cases were analyzed by NGS because of technical limitations, our results await further validation. In addition, the nuclear genome was not analyzed because of low coverage. In a recent study, no nDNA rearrangements were detected in addition to mtDNA mutations in renal oncocytomas. ${ }^{24}$

\section{Discussion}

We investigated the distribution of mtDNA mutations and the copy number of mtDNA in various cell types of the parathyroids, with and without COX activity, to elucidate the pathogenic mechanisms of oxyphil cell transformation. As the main result, we found different types of mtDNA point mutations, namely spatially restricted late somatic mutations representing putative pathogenic mutations and nonpathogenic mutations representing polymorphisms, distributed throughout the entire tissue. Specifically, we detected 29 putative pathogenic mutations, with only three occurring in two separate areas (Tables 5, 6, 7, 8, and 9). Among them, 11 mutations affected the $N D$ genes $N D 1$ and 3 to 6,2 affected the gene for cytochrome $b$, and 7 affected the COX genes $\mathrm{COI}$ to $\mathrm{COIII} ; 8$ were located in regulatory elements in the heavy strand promoter region, including the mitochondrial transcription factor binding site $\mathrm{H}$ locus.

Putative pathogenic point mutations occurred in all cell types of the parathyroids, but most often in pre-oxyphil/ oxyphil cells with and without COX deficiency (15 (83.3\%) of 18) (Tables 5 and 7) harboring $22(76 \%)$ of the $29 \mathrm{mu}-$ tations. Conversely, the mutation load was the lowest in 
Table 9 Comparison of mtDNA Mutations in the Three Histological Cell Types of the Parathyroids Displaying COX Positivity or Negativity

\begin{tabular}{|c|c|c|c|c|c|}
\hline \multicolumn{3}{|c|}{ COX-positive } & \multicolumn{3}{|c|}{ COX-negative } \\
\hline & $N D$ genes & CO genes & & $N D$ genes & CO genes \\
\hline Type 1 & ND5 & $\begin{array}{l}\text { COIII } \\
\text { COIII }\end{array}$ & Type 4 & ND6 & $\begin{array}{l}\text { 12S RNA } \\
16 S \text { RNA } \\
\text { COI }\end{array}$ \\
\hline Type 2 & $\begin{array}{l}\text { ND1 } \\
\text { ND3 }\end{array}$ & tRNA-Phe & Type 5 & ND4 & $\begin{array}{l}\text { COIII } \\
\text { CytB } \\
\text { D-loop (HSP)* } \\
\text { 16S RNA } \\
\text { 16S RNA } \\
\text { D-loop (MT-TFA) }\end{array}$ \\
\hline Type 3 & $\begin{array}{l}\text { ND4 } \\
\text { ND4* } \\
\text { ND5 } \\
\text { ND5 } \\
\text { ND5 }\end{array}$ & $\begin{array}{l}\text { COIII } \\
C O{ }^{*} \\
\text { CytB }\end{array}$ & Type 6 & $N D 4^{*}$ & $\begin{array}{l}\text { D-loop (HSP) } \\
\text { D-loop (HSP)* } \\
\text { COI* }^{*}\end{array}$ \\
\hline $\begin{array}{l}\sum_{P \text { value }}^{\text {Total }} \\
P\end{array}$ & 8 & $\begin{array}{l}6 \\
14\end{array}$ & & 3 & $\begin{array}{l}12 \\
15 \\
<0.001^{\dagger}\end{array}$ \\
\hline
\end{tabular}

Mutations in the respective identical cell types: type 1, 4 clear chief cell; type 2, 5 pre-oxyphil cell; type 3, 6 oxyphil cell.

*Early development mutation.

${ }^{\dagger} \chi^{2}$ Test.

HSP, H-strand promoter; MT-TFH, mitochondrial transcription factor binding site $\mathrm{H}$.

clear chief cells. Herein, only 3 (43\%) of 7 areas accumulated putative pathogenic mtDNA mutations, and of the 29 mutations, only 7 (24\%) affected this cell type (Table 7 ). The predominant accumulation of the point mutations in the pre-oxyphil/oxyphil cells was paralleled by our finding that pre-oxyphil/oxyphil cells harbored 75\% (65/87) of the COX defects, whereas clear chief cells displayed only $25 \%$ (22/87) (Table 2), thus confirming previous results. ${ }^{4,5}$
Moreover, we showed that putative pathogenic mutations of the $N D$ genes $N D 1$ and 3 to 6 preferentially $(P=0.046)$ accumulated in COX-positive cells [8 $(57.1 \%)$ of 14] (Table 9) compared with COX-negative cells [3 (20.0\%) of 15] (Table 9). Conversely, putative pathogenic mutations affecting COX activity (COX or other $C O X$-impairing genes) significantly $(P=0.046)$ accumulated in COXdeficient cells [11 (73.3\%) of 15] compared with COXpositive cells [5 $(35.7 \%)$ of 14$]$.

Because the $N D$ mutations dominated in the large population of regular pre-oxyphil/oxyphil cells with intact COX activity, they could represent the major/initial event for oxyphil cell transformation (ie, the induction of increased $\mathrm{mtDNA} /$ mitochondrial biogenesis starting probably from compromised mitochondria-poor clear chief cells). Mutations impairing COX activity, in contrast, were mainly restricted to the subgroup of pre-oxyphil/oxyphil cells with COX deficiency. Therefore, they could be responsible for the mtDNA/mitochondrial biogenesis in this subgroup. The role of the polymorphisms in this scenario remains unclear. Because they were ubiquitously present in multiple samples of the same patient, they were either inherited or occurred already early in development. ${ }^{36}$

The role of complex I-affecting $N D$ mutations of mtDNA in adaptive biogenesis of mtDNA/mitochondria is also supported by previous studies in which their preferential occurrence in oncocytomas of the kidneys and the thyroids has been described. ${ }^{23,24,26-28,30,37}$ Functional deficiency of complex I of the respiratory chain has been reported in oncocytomas of the kidneys, ${ }^{28,38}$ but not of the thyroids. ${ }^{39}$ Herein, a decreased ATP synthesis resulted from defective coupling of oxidative phosphorylation, probably caused by increased uncoupling protein. ${ }^{39}$ In a later study, nuclear factors, such as phosphatidyl glycerol phospholipase $\mathrm{C} 1$-related coactivator, and target genes, such as the nuclear respiratory factor 1 (NRF1) and the mitochondrial transcription factor A (TFAM), were shown to be activated. ${ }^{40}$

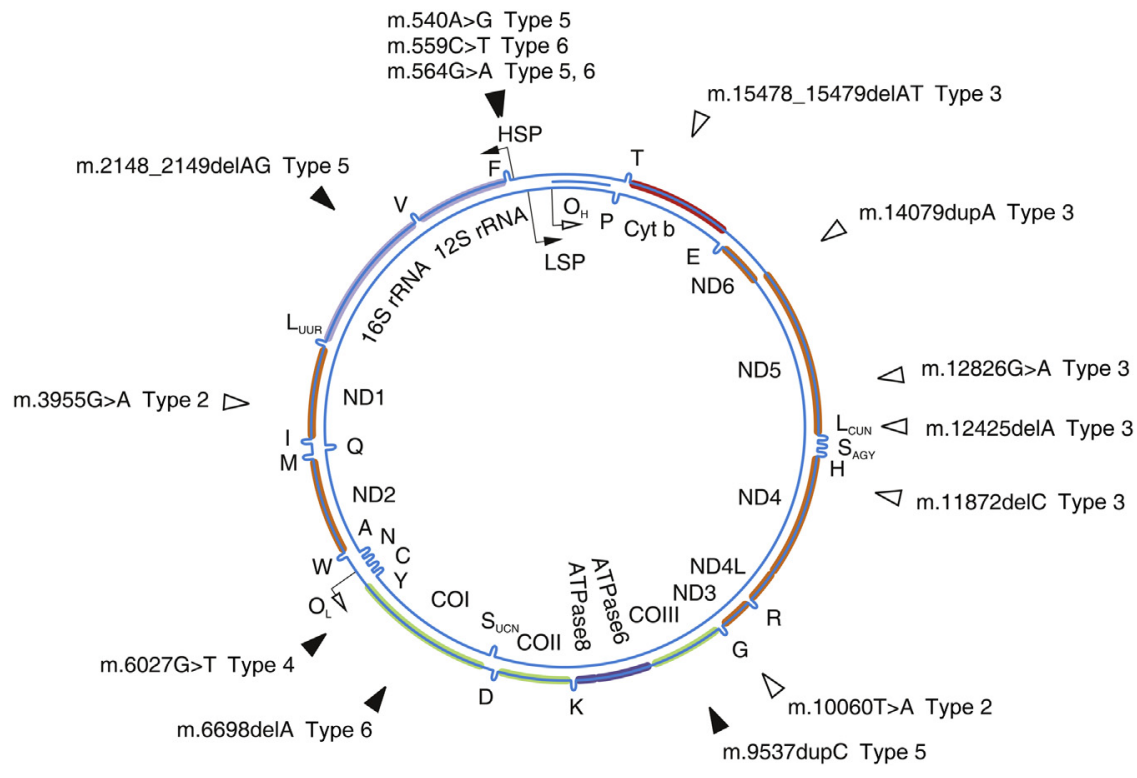

Figure 6 Gene map of mtDNA. Putative pathogenic mutations ( $>50 \%$ heteroplasmy) in COXpositive and COX-negative parathyroid cells. There is a predominance of ND mutations in COXpositive cells (white triangles), whereas in COXnegative cells (black triangles), mutations in the HSP region of the D-loop, in 16S rRNA gene, and in the genes MT-CO1 (COI) and MT-CO3 (COIII) are present. 
$N D$ mutations also predominated in pure (monoclonal) clear cell or oxyphil cell adenomas of the parathyroids. ${ }^{31}$ In none of these studies, however, was the activity of COX analyzed at the cellular level. Furthermore, in contrast to a previous study on the parathyroids, ${ }^{31}$ we investigated mixed clear/oxyphil cell adenomas and detected mtDNA mutations not only in adenomas but also in hyperplastic parathyroids by applying NGS.

In fact, $N D$ mutations, especially in $N D 1$, could represent a hot spot because of unstable homopolymer regions. ${ }^{37}$ The broad spectrum of the putative pathogenic mutations we found, encompassing mutations in structural $N D$ and $C O X$ genes as well as in regulatory elements of mtDNA, is similar to that observed in COX-deficient cells of colonic crypts ${ }^{41}$ and in clear/oxyphil cell adenomas of the parathyroids. ${ }^{31}$ On the other hand, in epithelial tissues such as liver, ${ }^{42}$ prostate, ${ }^{43,44}$ and urothelium, ${ }^{44}$ single-type mtDNA mutations accumulated, which neither affected ND genes nor were causative for the observed COX defects. Therefore, the pathogenic mechanisms of the COX defects remained unclear in these studies. Similarly, in the current study and in work on colonic crypt cells, ${ }^{41}$ some COX-deficient cell areas were present without harboring putative pathogenic mtDNA mutations. Herein, undetected nuclear or mtDNA mutations might be involved. Furthermore, we cannot explain the existence of COX-deficient clear chief cells (ie, why the adaptive process of mitochondrial proliferation responsible for oxyphil cell transformation was not established in these cells). A hypothetical explanation might be that for unknown reasons, the adaptive up-regulation of nuclear genes responsible for the biogenesis of $\mathrm{mtDNA} /$ mitochondria ${ }^{45-47}$ was deficient in these cases.

Irrespective of their disruptive potential, the mtDNA mutations observed herein in the parathyroids, but also those in liver, prostate, urothelium, and the gut, ${ }^{41-44,48}$ were apparently clonal and accumulated in solid cell aggregates, as already seen in histological/enzyme histochemical analysis. Because cell renewal generally is controlled by stem/ precursor cells, it is most likely that the mtDNA mutations primarily occurred in this cell type, leading to clonal expansion by cell division over time.

Similar to findings in colonic crypts, ${ }^{41}$ but contrary to what has been reported in liver, prostate, and urothelium, ${ }^{42-44,48}$ we found multiple mtDNA mutations in approximately half $(8 / 17)$ of the defect areas. Thus, stem cells with multiple mutations or multiple stem cells each with a single type of mutation have to be assumed.

Our finding that both single and multiple mutations occurred in a heteroplasmic state, their level varying between $20 \%$ and $93 \%$, also deserves a short comment. In colon crypts ${ }^{41}$ and the heart, ${ }^{49}$ mutations were mixed homoplasmic and heteroplasmic, whereas clonal adenomas of the parathyroids $^{31}$ were mostly homoplasmic (14/15), as was also the case in single-type mtDNA mutations of the prostate, ${ }^{43,48}$ urothelium, ${ }^{44}$ liver, ${ }^{42}$ and oncocytomas. ${ }^{24,28}$ Since in the present work, groups of cells were analyzed it remains unclear whether the observed heteroplasmy levels represented true intracellular heteroplasmy or resulted from variable mixtures of cells with substantially different mutation loads, reflecting, above all, the stochastic nature of the segregation process. In fact, the level of heteroplasmy is relevant for the pathological significance of mtDNA mutations. ${ }^{25,50}$ Consistently, we observed the highest levels of heteroplasmy in COX-negative pre-oxyphil/oxyphil lesions $(P<0.001)$.

In addition to point mutations, we also examined the presence of mtDNA deletions because these are well known to accumulate in post-mitotic tissues, such as brain, skeletal, and heart muscle during aging. ${ }^{3,51-56}$ We found that mtDNA deletions occurred in the parathyroids with nearly the same rate in both COX-positive (24\%) and COX-negative $(25 \%)$ lesions, and were increased only in a subfraction of clear chief cells with COX deficiency (Tables 2 and 3). Therefore, we conclude that deletions do not play a major role in oxyphil cell transformation and for the development of COX defects in the parathyroids. Most likely, they represent an additional, independent phenomenon of cellular aging. It remains, however, unclear whether they coexist with somatic mtDNA mutations in identical cells or even mitochondria. In the human colonic crypt cells with COX deficiency, deletions were even completely missing. ${ }^{41}$

Finally, the copy number of mtDNA was specifically addressed only in a few of the previously mentioned studies. We found that regular oxyphil cells had approximately 2.5fold more mtDNA than regular clear chief cells. This is similar to previous findings detecting increased mtDNA copy numbers in oncocytomas of the thyroid when compared with controls (threefold to fourfold). ${ }^{39,40}$ Surprisingly, the increase was even more pronounced in COX-deficient lesions (approximately fourfold). Moreover, COX-negative oxyphil cells had two times more mtDNA than COX-positive oxyphil cells $\left(\mathrm{Q}_{\mathrm{m} t / \mathrm{n}}: 1.74\right.$ versus 0.82 ; $P<0.001$ ) (Table 1). These results differ from those obtained in the colonic crypts, ${ }^{41}$ where an increase of the mtDNA copy number was not found, and from those in oncocytic liver cells, where mtDNA depletion was reported in COX deficiency. ${ }^{9}$ In contrast, our findings indicate that mtDNA biogenesis is triggered more severely by mtDNA mutations that cause COX deficiency than by oxidative phosphorylation deficiency related to ND mutations. This is consistent with the fact that $\mathrm{COX}$ is an important regulator of oxidative phosphorylation ${ }^{57,58}$ and supports previous findings that $P O L G$, the gene for the mtDNA polymerase $\gamma$, responsible for mtDNA replication, displays no pathogenic mutations in oncocytomas ${ }^{24}$ and is also intensively expressed in COX-deficient parathyroid cells. ${ }^{6}$

In summary, our results indicate that mtDNA mutations are the pathogenic determinants of oxyphil cell transformation and of COX deficiency in the parathyroids. On the basis of our present findings and the fact that both oxyphil cell transformation and COX defects increase with age in the parathyroids, we propose the following multiple-hit scenario: 
mtDNA mutations occur randomly in the course of cellular aging, many of which probably will later on disappear through stochastic processes of mtDNA turnover or mtDNA repair mechanisms. Some of the mutations, however, apparently undergo intracellular expansion and, when reaching a threshold level, cause functional disturbances. Such dysfunctions, probably occurring initially in mitochondria-poor clear chief cells, would induce a compensatory mitochondrial proliferation manifesting as oxyphil cell transformation in the parathyroids. High levels of mutations in subunits of complex IV or in regions of the mtDNA that play a critical role in the mitochondrial protein biosynthesis would result in COX deficiency, whereas mutations in complex I subunits specifically affect complex I function. Thus, $N D$ mutations might be essential for initiating oxyphil cell transformation in compromised mitochondria-poor clear chief cells.

The differing distributions of the mutations in COXpositive and COX-negative lesions reflects either selection or random segregation, either early in development or later in life, ${ }^{36,59}$ during cellular aging ${ }^{59-66}$; therefore, the mutations represent most probably expanding, but not continuous, de novo alterations. . $^{5,59,67}$

It is possible that, in addition to stochastic processes, various factors influencing mtDNA replication, such as defective mtDNA polymerase $\gamma$, insufficient mtDNA repair, and others, ${ }^{68-72}$ play a significant role in generation and propagation of mtDNA mutations. At least the role of continuous de novo generation of mutations by oxidative damage appears rather negligible in this scenario because 8-OH-guanosine-induced $\mathrm{G}>\mathrm{T}$ transversions do not accumulate with age. ${ }^{49,56,64,69}$

A potential role of the polymorphisms is still elusive. Their ubiquitous presence in the tissue suggests that they apparently occurred early in development. In contrast, putative pathogenic ND and COX mutations were mainly restricted to single groups of cells; thus, they most likely represent later somatic events in cellular aging. Consequently, COX deficiency does not represent a secondary event related to an ongoing accumulation of early mtDNA mutations, but most probably results directly from later-occurring de novo somatic mutations that apparently segregate independent from ND mutations. Further studies on a larger series will be helpful to clarify whether the described spectrum of mtDNA mutations is a general feature of oxyphil cell transformation occurring also in oxyphil cells of other epithelial organs.

\section{Acknowledgments}

We thank Birgitt Löffler (Molekulare Zellbiologie Leipzig) for technical assistance and Eric A. Schon (Columbia University Medical Center, New York, NY) for critically reading the manuscript.

J.M.-H., S.S., and A.J. performed the histological/enzymehistochemical work, the microdissection of tissue, and isolation of the DNA; S.K. and H.B. performed NGS; G.Z.,
W.S.K., and H.P. performed the bioinformatoric analyses of the data from NGS; P.S. was responsible for the performance and analysis of qPCR studies; and J.M.-H. and A.J. planned and supervised the work and wrote the manuscript.

\section{References}

1. Akerstrom G, Rudberg C, Grimelius L, Bergstrom R, Johansson H, Ljunghall S, Rastad J: Histologic parathyroid abnormalities in an autopsy series. Hum Pathol 1986, 17:520-527

2. Poche R: On the effect of dinitrophenol and thyroxin on the ultrastructure of the myocardium in the rat [German]. Virchows Arch Pathol Anat Physiol Klin Med 1962, 335:282-452

3. Tremblay G: Oncocytes, a review. Methods Achievements Exp Pathol 1969, 4:121-140

4. Muller-Hocker J, Aust D, Napiwotzky J, Munscher C, Link TA, Seibel P, Schneeweiss SG, Kadenbach B: Defects of the respiratory chain in oxyphil and chief cells of the normal parathyroid and in hyperfunction. Hum Pathol 1996, 27:532-541

5. Muller-Hocker J: Random cytochrome-C-oxidase deficiency of oxyphil cell nodules in the parathyroid gland: a mitochondrial cytopathy related to cell ageing? Pathol Res Pract 1992, 188:701-706

6. Muller-Hocker J, Schafer S, Copeland WC, Wiesner R, Seibel P: Immunohistochemical detection of human mtDNA polymerase gamma and of human mitochondrial transcription factor $\mathrm{A}$ in cytochrome-c-oxidase-deficient oxyphil cells of hyperfunctional parathyroids. Virchows Arch 1998, 433:529-536

7. Muller-Hocker J: Defects of the respiratory chain in hepatic oncocytes. Virchows Arch 1998, 432:349-356

8. Muller-Hocker J, Aust D, Rohrbach H, Napiwotzky J, Reith A, Link TA, Seibel P, Holzel D, Kadenbach B: Defects of the respiratory chain in the normal human liver and in cirrhosis during aging. Hepatology 1997, 26:709-719

9. Tanji K, Bhagat G, Vu TH, Monzon L, Bonilla E, Lefkowitch JH: Mitochondrial DNA dysfunction in oncocytic hepatocytes. Liver Int 2003, 23:397-403

10. Andreu AL, DiMauro S: Current classification of mitochondrial disorders. J Neurol 2003, 250:1403-1406

11. DiMauro S, Hirano M: Mitochondrial encephalomyopathies: an update. Neuromuscul Disord 2005, 15:276-286

12. Greaves LC, Reeve AK, Taylor RW, Turnbull DM: Mitochondrial DNA and disease. J Pathol 2012, 226:274-286

13. Lenaz G, Baracca A, Carelli V, D’Aurelio M, Sgarbi G, Solaini G: Bioenergetics of mitochondrial diseases associated with mtDNA mutations. Biochim Biophys Acta 2004, 1658:89-94

14. Schon EA, DiMauro S, Hirano M: Human mitochondrial DNA: roles of inherited and somatic mutations. Nat Rev Genet 2012, 13: $878-890$

15. Taylor RW, Turnbull DM: Mitochondrial DNA mutations in human disease. Nat Rev Genet 2005, 6:389-402

16. Wallace DC: Diseases of the mitochondrial DNA. Annu Rev Biochem 1992, 61:1175-1212

17. Ylikallio E, Suomalainen A: Mechanisms of mitochondrial diseases. Ann Med 2012, 44:41-59

18. Zeviani M, Di Donato S: Mitochondrial disorders. Brain 2004, 127 2153-2172

19. Muller-Hocker J, Jacob U, Seibel P: Hashimoto thyroiditis is associated with defects of cytochrome-c oxidase in oxyphil Askanazy cells and with the common deletion $(4,977)$ of mitochondrial DNA. Ultrastruct Pathol 1998, 22:91-100

20. Maximo V, Sobrinho-Simoes M: Mitochondrial DNA "common" deletion in Hurthle cell lesions of the thyroid. J Pathol 2000, 192: $561-562$

21. Maximo V, Sores P, Rocha AS, Sobrinho-Simoes M: The common deletion of mitochondrial DNA is found in goiters and thyroid tumors 
with and without oxyphil cell change. Ultrastruct Pathol 1998, 22: $271-273$

22. Lewis PD, Baxter P, Paul Griffiths A, Parry JM, Skibinski DO: Detection of damage to the mitochondrial genome in the oncocytic cells of Warthin's tumour. J Pathol 2000, 191:274-281

23. Bonora E, Porcelli AM, Gasparre G, Biondi A, Ghelli A, Carelli V, Baracca A, Tallini G, Martinuzzi A, Lenaz G, Rugolo M, Romeo G: Defective oxidative phosphorylation in thyroid oncocytic carcinoma is associated with pathogenic mitochondrial DNA mutations affecting complexes I and III. Cancer Res 2006, 66:6087-6096

24. Gasparre G, Hervouet E, de Laplanche E, Demont J, Pennisi LF, Colombel M, Mege-Lechevallier F, Scoazec JY, Bonora E, Smeets R, Smeitink J, Lazar V, Lespinasse J, Giraud S, Godinot C, Romeo G, Simonnet H: Clonal expansion of mutated mitochondrial DNA is associated with tumor formation and complex I deficiency in the benign renal oncocytoma. Hum Mol Genet 2008, 17:986-995

25. Gasparre G, Kurelac I, Capristo M, Iommarini L, Ghelli A, Ceccarelli C, Nicoletti G, Nanni P, De Giovanni C, Scotlandi K, Betts CM, Carelli V, Lollini PL, Romeo G, Rugolo M, Porcelli AM: A mutation threshold distinguishes the antitumorigenic effects of the mitochondrial gene MTND1, an oncojanus function. Cancer Res $2011,71: 6220-6229$

26. Maximo V, Lima J, Prazeres H, Soares P, Sobrinho-Simoes M: The biology and the genetics of Hurthle cell tumors of the thyroid. Endocr Relat Cancer 2012, 19:R131-R147

27. Maximo V, Soares P, Lima J, Cameselle-Teijeiro J, SobrinhoSimoes M: Mitochondrial DNA somatic mutations (point mutations and large deletions) and mitochondrial DNA variants in human thyroid pathology: a study with emphasis on Hurthle cell tumors. Am J Pathol 2002, 160:1857-1865

28. Mayr JA, Meierhofer D, Zimmermann F, Feichtinger R, Kogler C, Ratschek M, Schmeller N, Sperl W, Kofler B: Loss of complex I due to mitochondrial DNA mutations in renal oncocytoma. Clin Cancer Res 2008, 14:2270-2275

29. Pereira L, Soares P, Maximo V, Samuels DC: Somatic mitochondrial DNA mutations in cancer escape purifying selection and high pathogenicity mutations lead to the oncocytic phenotype: pathogenicity analysis of reported somatic mtDNA mutations in tumors. BMC Cancer 2012, 12:53

30. Zimmermann FA, Mayr JA, Feichtinger R, Neureiter D, Lechner R, Koegler C, Ratschek M, Rusmir H, Sargsyan K, Sperl W, Kofler B: Respiratory chain complex I is a mitochondrial tumor suppressor of oncocytic tumors. Front Biosci (Elite Ed) 2011, 3:315-325

31. Costa-Guda J, Tokura T, Roth SI, Arnold A: Mitochondrial DNA mutations in oxyphilic and chief cell parathyroid adenomas. BMC Endocr Disord 2007, 7:8

32. Sciacco M, Bonilla E, Schon EA, DiMauro S, Moraes CT: Distribution of wild-type and common deletion forms of mtDNA in normal and respiration-deficient muscle fibers from patients with mitochondrial myopathy. Hum Mol Genet 1994, 3:13-19

33. Bender A, Krishnan KJ, Morris CM, Taylor GA, Reeve AK, Perry RH, Jaros E, Hersheson JS, Betts J, Klopstock T, Taylor RW, Turnbull DM: High levels of mitochondrial DNA deletions in substantia nigra neurons in aging and Parkinson disease. Nat Genet 2006, 38:515-517

34. He L, Chinnery PF, Durham SE, Blakely EL, Wardell TM, Borthwick GM, Taylor RW, Turnbull DM: Detection and quantification of mitochondrial DNA deletions in individual cells by realtime PCR. Nucleic Acids Res 2002, 30:e68

35. Goecks J, Nekrutenko A, Taylor J: Galaxy: a comprehensive approach for supporting accessible, reproducible, and transparent computational research in the life sciences. Genome Biol 2010, 11:R86

36. He Y, Wu J, Dressman DC, Iacobuzio-Donahue C, Markowitz SD, Velculescu VE, Diaz LA Jr, Kinzler KW, Vogelstein B, Papadopoulos N: Heteroplasmic mitochondrial DNA mutations in normal and tumour cells. Nature 2010, 464:610-614
37. Gasparre G, Romeo G, Rugolo M, Porcelli AM: Learning from oncocytic tumors: why choose inefficient mitochondria? Biochim Biophys Acta 2011, 1807:633-642

38. Simonnet H, Demont J, Pfeiffer K, Guenaneche L, Bouvier R, Brandt U, Schagger H, Godinot C: Mitochondrial complex $\mathrm{I}$ is deficient in renal oncocytomas. Carcinogenesis 2003, 24:1461-1466

39. Savagner F, Franc B, Guyetant S, Rodien P, Reynier P, Malthiery Y: Defective mitochondrial ATP synthesis in oxyphilic thyroid tumors. J Clin Endocrinol Metab 2001, 86:4920-4925

40. Savagner F, Mirebeau D, Jacques C, Guyetant S, Morgan C, Franc B, Reynier P, Malthiery Y: PGC-1-related coactivator and targets are upregulated in thyroid oncocytoma. Biochem Biophys Res Commun 2003, 310:779-784

41. Taylor RW, Barron MJ, Borthwick GM, Gospel A, Chinnery PF, Samuels DC, Taylor GA, Plusa SM, Needham SJ, Greaves LC, Kirkwood TB, Ttay DM: Mitochondrial DNA mutations in human colonic crypt stem cells. J Clin Invest 2003, 112:1351-1360

42. Fellous TG, Islam S, Tadrous PJ, Elia G, Kocher HM, Bhattacharya S, Mears L, Turnbull DM, Taylor RW, Greaves LC, Chinnery PF, Taylor G, McDonald SA, Wright NA, Alison MR: Locating the stem cell niche and tracing hepatocyte lineages in human liver. Hepatology 2009, 49:1655-1663

43. Blackwood JK, Williamson SC, Greaves LC, Wilson L, Rigas AC, Sandher R, Pickard RS, Robson CN, Turnbull DM, Taylor RW, Heer R: In situ lineage tracking of human prostatic epithelial stem cell fate reveals a common clonal origin for basal and luminal cells. J Pathol 2011, 225:181-188

44. Gaisa NT, Graham TA, McDonald SA, Canadillas-Lopez S, Poulsom R, Heidenreich A, Jakse G, Tadrous PJ, Knuechel R, Wright NA: The human urothelium consists of multiple clonal units, each maintained by a stem cell. J Pathol 2011, 225: 163-171

45. Clayton DA: Replication and transcription of vertebrate mitochondrial DNA. Annu Rev Cell Biol 1991, 7:453-478

46. Falkenberg M, Larsson NG, Gustafsson CM: DNA replication and transcription in mammalian mitochondria. Annu Rev Biochem 2007, 76:679-699

47. Scarpulla RC: Transcriptional activators and coactivators in the nuclear control of mitochondrial function in mammalian cells. Gene 2002, 286:81-89

48. Gaisa NT, Graham TA, McDonald SA, Poulsom R, Heidenreich A, Jakse G, Knuechel R, Wright NA: Clonal architecture of human prostatic epithelium in benign and malignant conditions. J Pathol 2011, 225:172-180

49. Nekhaeva E, Bodyak ND, Kraytsberg Y, McGrath SB, Van Orsouw NJ, Pluzhnikov A, Wei JY, Vijg J, Khrapko K: Clonally expanded mtDNA point mutations are abundant in individual cells of human tissues. Proc Natl Acad Sci U S A 2002, 99:5521-5526

50. D'Aurelio M, Gajewski CD, Lenaz G, Manfredi G: Respiratory chain supercomplexes set the threshold for respiration defects in human mtDNA mutant cybrids. Hum Mol Genet 2006, 15: $2157-2169$

51. Brierley EJ, Johnson MA, Lightowlers RN, James OF, Turnbull DM: Role of mitochondrial DNA mutations in human aging: implications for the central nervous system and muscle. Ann Neurol 1998, 43: 217-223

52. Cortopassi GA, Arnheim N: Detection of a specific mitochondrial DNA deletion in tissues of older humans. Nucleic Acids Res 1990, 18:6927-6933

53. Khrapko K, Bodyak N, Thilly WG, van Orsouw NJ, Zhang X, Coller HA, Perls TT, Upton M, Vijg J, Wei JY: Cell-by-cell scanning of whole mitochondrial genomes in aged human heart reveals a significant fraction of myocytes with clonally expanded deletions. Nucleic Acids Res 1999, 27:2434-2441

54. Kraytsberg Y, Kudryavtseva E, McKee AC, Geula C, Kowall NW, Khrapko K: Mitochondrial DNA deletions are abundant and cause 
functional impairment in aged human substantia nigra neurons. Nat Genet 2006, 38:518-520

55. Lee HC, Wei YH: Mitochondria and aging. Adv Exp Med Biol 2012, 942:311-327

56. Williams SL, Mash DC, Zuchner S, Moraes CT: Somatic mtDNA mutation spectra in the aging human putamen. PLoS Genet 2013, 9: e1003990

57. Kunz WS, Kudin A, Vielhaber S, Elger CE, Attardi G, Villani G: Flux control of cytochrome c oxidase in human skeletal muscle. J Biol Chem 2000, 275:27741-27745

58. Villani G, Attardi G: In vivo control of respiration by cytochrome c oxidase in wild-type and mitochondrial DNA mutation-carrying human cells. Proc Natl Acad Sci U S A 1997, 94:1166-1171

59. Khrapko K: The timing of mitochondrial DNA mutations in aging. Nat Genet 2011, 43:726-727

60. Calloway CD, Reynolds RL, Herrin GL Jr, Anderson WW: The frequency of heteroplasmy in the HVII region of mtDNA differs across tissue types and increases with age. Am J Hum Genet 2000, 66:1384-1397

61. Cottrell DA, Turnbull DM: Mitochondria and ageing. Curr Opin Clin Nutr Metab Care 2000, 3:473-478

62. Greaves LC, Turnbull DM: Mitochondrial DNA mutations and ageing. Biochim Biophys Acta 2009, 1790:1015-1020

63. Linnane AW, Marzuki S, Ozawa T, Tanaka M: Mitochondrial DNA mutations as an important contributor to ageing and degenerative diseases. Lancet 1989, 1:642-645
64. Michikawa Y, Mazzucchelli F, Bresolin N, Scarlato G, Attardi G: Aging-dependent large accumulation of point mutations in the human mtDNA control region for replication. Science 1999, 286:774-779

65. Miquel J, Economos AC, Fleming J, Johnson JE Jr: Mitochondrial role in cell aging. Exp Gerontol 1980, 15:575-591

66. Sondheimer N, Glatz CE, Tirone JE, Deardorff MA, Krieger AM, Hakonarson H: Neutral mitochondrial heteroplasmy and the influence of aging. Hum Mol Genet 2011, 20:1653-1659

67. Elson JL, Samuels DC, Turnbull DM, Chinnery PF: Random intracellular drift explains the clonal expansion of mitochondrial DNA mutations with age. Am J Hum Genet 2001, 68:802-806

68. Cadenas E, Davies KJ: Mitochondrial free radical generation, oxidative stress, and aging. Free Radic Biol Med 2000, 29:222-230

69. Kennedy SR, Salk JJ, Schmitt MW, Loeb LA: Ultra-sensitive sequencing reveals an age-related increase in somatic mitochondrial mutations that are inconsistent with oxidative damage. PLoS Genet 2013, 9:e1003794

70. Khrapko K, Vijg J: Mitochondrial DNA mutations and aging: devils in the details? trends in genetics. Trends Genet 2009, 25:91-98

71. Richter C, Park JW, Ames BN: Normal oxidative damage to mitochondrial and nuclear DNA is extensive. Proc Natl Acad Sci U S A 1988, 85:6465-6467

72. Wiesner RJ, Zsurka G, Kunz WS: Mitochondrial DNA damage and the aging process: facts and imaginations. Free Radic Res 2006, 40: $1284-1294$ 